\title{
コンクリートの初期性状 (1)
}

笠 井 芳 夫*

1.コンクリートの初期性状とはどのよう な性状をいうのが

コンクリートの性質のうち, 型わくに打込むまでの性 質については, 調合を定めたり, 運搬・施工性との関係 において多数の実験研究が報告されている。ところが型 わくに打込んでから硬化するまでの期間, 特に型わくに 打込んだ直後から材令 3 日位までのコンクリートについ ては研究がごく少なかった。“コンクリートは硬化した 状態で使用するものであり, 型わくに打込儿でしまえば コンクリートがどのような過程を経て硬化しようと, 最 終品質さえ確保されればよいのであって, 硬化過程など については, それ程気を使うことはない”という見方を すれば無理もないことであった。

ところが，“コンクリートを型わくに打込んだ直後か ら硬化初期における養生のあり方が, 硬化後のコンクリ 一トの品質に影響する”ということが明らかになるにつ れて，初期性状に関する報告が多くなった。

しからば，“初期とはどの程度をでの期間を言うのか” となると, 明確な定義はないが, 普通, 早強, 混合ポル トランドセメントについては後に述べるように， $20^{\circ} \mathrm{C}$, 3 日以内と考えてよかろう。超早強ポルトランドセメン トでは強度発現が極めて早いため, $20^{\circ} \mathrm{C}, 24$ 時間以内程 度とみなしてよかろら

なお英語では early (形容詞), early age (名詞) など という語を用いているが, 材令 1 週位までのある程度硬 化したコンクリートを green concrete (若材令コンクリ 一ト)などと呼ぶこともある。

初期性状と密接な関係をもつ 主なコンクリートの性 質・応用例を示せば以下のようである。

i) 側庄 (支保工の設計)

$*$ 正会員 日本大学教授 生産工学部建築工学科 ii ） 容積変化（ブリージング, 沈下, 初期ひびわれ， 水平筋の下端のあき, 再打法)

iii）凝結性状（凝結時間, 打継ぎ許容時間, コテ仕 上時間)

iv ) 初期強度（初期圧縮強度, 初期引張強度, 型わ く引技摩擦力, スリップフォーム工法に抢けるコンクリ 一トの初期圧縮強度推定, 養生打切り時強度の推定な ど)。

v) 初期楸生（養生切り時期の決定, 凍害耐力, 初 期凍害, 初期乾燥, 熱帯コンクリート, コンクリートの 発熱, 初期における振動, 水中における初期損耗など)。 以上コンクリートの初期性状で取扱ら範囲を述べた が，それぞれについては，これから解説を進めて行きた い。

2.コンクリートの側圧はどのように作用 するか

コンクリートを打設すると型わくが変形したり，まれ に型わくが破壊（ぱんく）して事故を起こすことがあ る。これはコンクリートがその自重によって圧力を型わ くに作用させるためである。この型わくに作用する庄力 を側圧と呼んでいる。

一般に液柱の自重による圧力は液柱の高さ(これを液 頭 : liquid head ともいう) に比例するが，コンクリー トの側庄は必ずしも打込み高さに正比例しない。以下そ の理由につマて述べる。

コンクリートの打込み高さと最下部の側圧との関係を 例示すれば 图一1 のようである。この図の例では, 柱の 場合コンクリートの高さの約 $1.3 \mathrm{~m}$ のとき側圧は最大 值をとり, その值は約 $3.0 \mathrm{t} / \mathrm{m}^{2}$ である。高さ $1 \mathrm{~m}$ の場 合側圧就 $2.3 \mathrm{t} / \mathrm{m}^{2}$ で, 打込み高さと, 側圧の関係が直 線関係をとる範囲では, 液体圧と同様になることがわか 


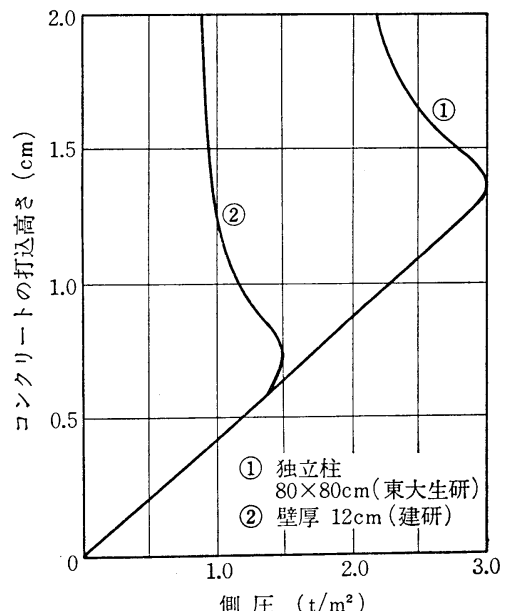

側 圧 $\left(t / \mathrm{m}^{2}\right)$

図一1 コンクリートの打込み高さと最低部の側圧（例示）

る。その後は高さが増えても側圧は大きくならず，かえ って最下部の側圧は減少している。壁の場合, 側圧の最 大值はずっと小さい值をとっている。

コンクリートの側圧がある大きさで最大值をとるの は，型わくがコンクリートの自重を支える働き（作用） をしているからであるがこの作用を迫持ち作用といい， 型わくの横断面の内法寸法が小さい程迫持作用は大きい (壁の方が柱より迫持作用が大きい)。

迫持ち作用の模式図を示せば 図一2 のようである。コ ンクリートは粗骨材を多量に含むため, 自重による下向 きの力が, 主として粗骨材から粗骨材へと伝達されてゆ く過程において, この下向の力はやがて横向きの力に変 わり，型わくを斜め下横向きに押すカとして，コンクリ 一トの自重を支えてしまうことがわかる。型わくの断面 寸法が小さいほど，型わくがコンクリートを支持する範 囲が小さいため側圧が小さくなるものと考えてよい。

次に側圧が最大值をとった後減少するのは, コンクリ 一トが次第にマトリックスを形成してくるためである。 これは打込速度（速いと側圧の最大值は大きくなる）型

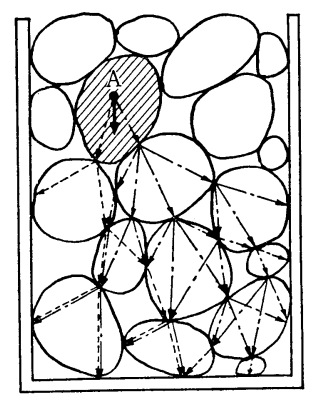

図一2 型わくの迫持ち作用模式図（図中Aという 粗骨材の自重は型わくに作用する横向きの カとして支持され次第に隇少する)

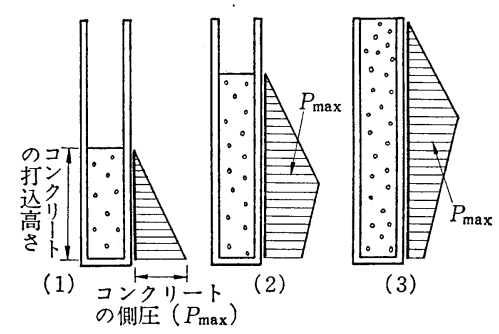

（1）コンクリートの側圧は打込高さに比例して大きく なり，底部が最大側圧 $P_{\max }$ になったとき

(2) $P_{\max }$ の位置が上に移る。

（3）コンクリートの打込み終了状態

\section{図一3 コンクリートの打込み高さと任意位置の側圧模式図}

わくの水漏れの程度（水漏れがあると側圧は急激に減少 する)、コンクリート温度（温度が高いとセメントの水 和が促進され側圧は速やかに減少する), その他スランプ の大小, 骨材の粗粒率, 振動機のかけ方, 鉄筋量などに よっても相違する。

图一3 はコンクリートの打込み高さと各位置に抒ける 側圧を図示したものである。最大側圧 $\left(P_{\max }\right)$ が次第 に上部に移動してゅくことを示している。したがって型 わくは完全率を見込んで側圧に耐えるように支保工を配 置する。

3.コンクリートの沈降・ブリージグとは どんなことか，これによって何が起こ るか

コンクリートを型わくに打込んでしばらくすると上面 に水がしみ出してくる。スランプ $22 \mathrm{~cm}$ 位の軟練りコン クリートを柱などに打込んでしばらくするとコンクリー 卜上表面に小さな穴ができて，そこから水が涌き出して くるのが観察される。この穴を水道と呼んでいる。この ような浮き水現象をブリージング (bleeding) と呼んで いる。英語の動詞 bleed には “血が出る”, “液汁がしみ 出る”という意味がある。“水がしみ出してくること” あるいは “しみ出してきた水”をブリージングというが， “ブリージング水”ともいう。

ブリージングは “水が下から上に流れる現象”である が，なぜこのようなことが生ずるのであろうか。通常砂 利, 砂などを箱につめて上から水を注いだ場合, 空気泡 がどんどん上に昇ってくるが，水が下から湧き出してく るような現象は見られない。

コンクリートはセメント (比重約 3.15), 骨材 (比重 約 2.65), 水（比重 1.00）を練り混ぜたもので, 単位水 量の多いコンクリートを型わくに打設し, 締固めると, モルタル中（セメントと砂の間隚）に含まれていた水が 分離し, セメント・骨材に比較して比重が小さく, かつ 流動し易いため，上方へ浮き上ってくる。見方を変えれ 


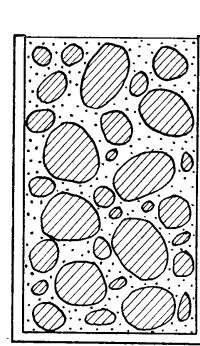

(a) 打設直後

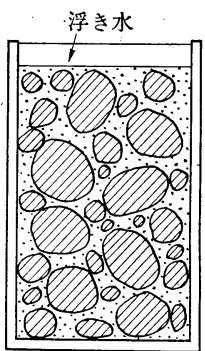

(b) 沈降・ブリージング後
図一4 沈降・ブリージング前後の比較模式図（骨材や セメントが沈降し水が追い出されて上に集まっ てくる)

ば，セメント・骨材などがわずかに下方に沈降し，それ まで水の占めていた場所を骨材が占めるようになり，水 が追出されて上へ浮き上ってくるのである。従ってブリ ージングは単位水量の多い程, 多くなる。

ブリージングに影響する因子をあげれば次のようであ る。

（i） セメント 粉末度の大きいほどブリージング は小さい。一般に液体中に存在する粒子が細い程, 粒子 の比表面積が大きいため, 水との接触面積 が大きくな り, 粒子の懸濁性が大きく, 保水性がよい。従って粒子 が細い程水とその粒子は分離し難い。またセメントの凝 結が早いとブリージングは生じ難い。これは水が分離し て上方へ移動するためには，そのための時間が必要であ るが，凝結の早いセメントはすぐにマトリックス（硬化 体としての組織）を作り，水の移動を妨げてしまうため である。例えば超速硬セメントなどでは，ブリージング を生ずる层もなく硬化してしまう。冬期にブリージング の続く時間が長いのはセメントの凝結が遅れるためであ る。

（ii）骨材 細い砂を用いる程ブリージングは小さ くなる筈であるが, 実際には細砂を用いる場合, 細骨材 率を小さくできるので，必ずしもそのようにならない。 䂺石コンクリートと普通骨材コンクリートとでは, 前者 の方がブリージングが大きい。この主な理由は同一スラ ンプの場合, 前者の単位水量が 8〜10\%大きくなるため である。

（iii） 混和材料 $\mathrm{AE}$ 剂・減水剤はコンクリートの 単位水量を減少し得るので,ブリージングは少なくなる。 特に AE 剂は連行空気が材料の分離を防ぐのでブリー ジングを少なくする。

フライアッシュなどを用いた場合, ブリージングは大 きくなる場合と小さくなる場合があり，必ずしも一定の 傾向を示さない。これはフライアッシュの使用の有無が それ程ブリージングに影響しないとも言える。
(iv) 配 (調) 合
配合のうち，ブリージングに対

する影響が最も大きいのは単位水量である。特にスラン プが $19 \mathrm{~cm}$ 位を超すとブリージングは急に増える。次は 単位砂量が少なくなるとブリージングが増える。西忠雄 博士 ${ }^{1-22)}$ は次式を提案している。

$$
B=S^{n} \cdot \alpha
$$

ここに $B:$ ブリージング量, $S$ : 単位砂量, $n$ および $\alpha$ は実験定数である。

（v）施工振動締固めが過度であると, 水の分離 のチャンスが大きくなり，ブリージングは増える。モル タル・コンクリートにコテを掛けると浮き水を生ずる。 これは骨材・セメントなどの間偗を小さくし，水を追出 すような作業を行うからである。打込速度が速いと, ブ リージングは増える。ポンプを用い独立柱のコンクリー トを一気に打上げるような場合は，ブリージングが大き くなる（この場合最大側圧も大きくなる）。

水漏れの少ない合板型わく, 鉄板型わくなどでは一般 にブリージングが大きい。柱・壁のコンクリートから硬 化後コアーを採取して強度を試験すると高さ方向上部の 強度は中央部の強度より 5〜15\% 位小さい，これはブリ ージングによって上部の水セメント比が大きくなるため である (図一5 参照)。打設後ある程度時間をおき, コン クリートが落着いてから, 試料を採取して水セメント比 を測定した神田衛博士 ${ }^{3)}$ らの結果によると，W/C 60\%， スランプ $21 \mathrm{~cm}$ のコンクリートでは上層部の水セメント 比は打込んだコンクリートより 5〜6\% 大きくなった。 またブリージングと共に比重の㪕い石膏粉, 骨材中の微 粒分などが上部に集って来て, コンクリート表面にレイ タンス（硬化後コンクリート表面に付着しているので, あべかおともいう) ができる。レイタンスは強度のない 物質であるから，この上に次のコンクリートを打継いで も一体とならないので, 予め取去るようにする。特にダ ム, 貯水タンクなどでは打継ぎの処理を確りやらないと 漏水の原因となる。レイタンスは材令 1 日以内に上面を

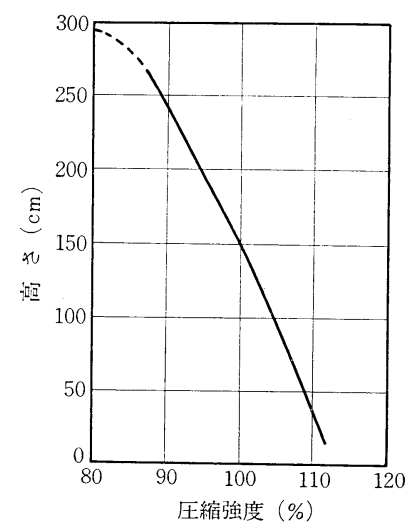

図一5 柱の高さ方向の強度差の例（高さ方向の中 央部の強度を 100 とした場合) 


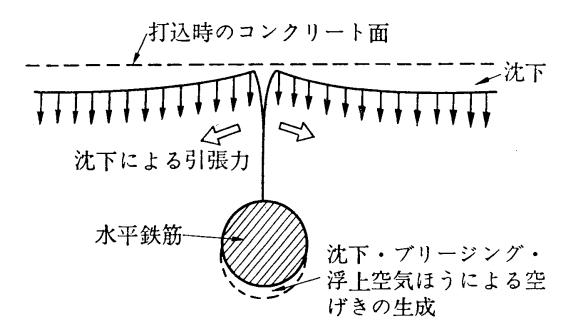

図一6 コンクリートの沈下による鉄筋上端に沿ったひ びわれと鉄筋下端の空げきの生成

目荒して洗うか, ウォータジェットなどで洗い流してし まうのがよい。

ブリージングは同時にコンクリートの沈下を伴う。ブ リージング量と沈下量はほぼ等しい。沈下によって水平 筋の上端に沿って初期ひびわれを発生することがある。 これは図一6 のように水平筋は動かないのにコンクリー トは沈下して鉄筋上端に沿って下向き両側にコンクリー トが引張られるためである。同時に鉄筋の下端には沈 下・ブリージング, 浮上空気の引掛りなどにより空隚が できる。水平筋の付着力を垂直筋の $1 / 2$ としているのは このためである。鉄筋上面に沿って発生したひびわれ は，コンクリートがまだやわらかい状態であれば，約 $10.5 \mathrm{~cm}$ 角, 長さ $4 \mathrm{~m}$ 程度の角材の両端に取手をつけ二 人で持って吒けば防止することができる。これは同時に 水平筋の付着力の改善をむたらす。この方法を再打法 (retamping) という。

均質な構造物を作るためにもブリージングの少ないコ ンクリートを施工するように心脚けなければならない。

\section{4. コンクリートの凝結とはどのような性 状か $^{1-10)}$}

水セメント比 $60 \%$ 程度の軟練りコンクリートを $20^{\circ} \mathrm{C}$ 室中で型わくに打込み, 観察していると, はじめコンク リートは水ぽく,ぶよぶよした感じであるが，やがて水 引けが始る頃から固ったようになり, 指先などでも強く 押さないと跡がつかなくなる。水セメント比 $60 \%$ の軟 練りコンクリートについて行った実験では, 加水後 4 時 位経過すると，片手でスランプ試験用の棒で突くと, 20 $\mathrm{mm}$ 位の穴があき, 棒状振動機を用いるとプラスチック になる（このときの強度 $0.32 \mathrm{~kg} / \mathrm{cm}^{2}$ ), 6 時間では片手 で棒突きすると表面がボロボロくずれたようになって穴 があいた。振動機を掛けるとプラスチックになるが，振 動を止めると直ちにこわばりはじめた。このときの強度 は $0.90 \mathrm{~kg} / \mathrm{cm}^{2}$ であった。 8 時間では片手で棒突きする と, 1〜2 mm 凹むが，振動機をかけると表面はボロボ ロになるのみで, プラスチックにはならない。このとき
の強度は $3.3 \mathrm{~kg} / \mathrm{cm}^{2}$ であった。このようにコンクリー 卜は時間経過と共に凝結し, やがて硬化することがわか る。

そこでこの凝結過程を定量的に示す試験方法がいろい ろ提案されているが1-3 9), 最も普及しているのは， セ メントの凝結試験と同様の発想によるもので，プロクタ 一貫入抵抗針による凝結時間試験方法（ASTM C-403） である。この方法は土の地耐力に関係する指標を得るた めに考案されたものであるが，これをコンクリートに適 用して凝結遅延剂の効果を明らかにすることができるこ とがわかり，凝結時間の測定に用いられるようになっ た。

ウェットスクリーンニングしたモルタルを 図一7のよ らな装置の先端の針を最初は太い針（断面積 $1 \mathrm{in}^{2}$ )を 用い，凝結の進行に伴って細い針に変えながら，先端が コンクリート中に深さ1インチ貫入した（押込んだ）と きの単位面積当りの押込み力を測定するものである。こ の方法で始発は $500 \mathrm{psi}$ (約 $35 \mathrm{~kg} / \mathrm{cm}^{2}$ ) とし, 終結は 貫入抵抗 $4000 \mathrm{psi}$ (約 $280 \mathrm{~kg} / \mathrm{cm}^{2}$ ) と定めているが, これはコンクリートの施工と特に関連づけられたもので はない。烏田博士はこの点について研究され, 後述 $\mathbf{5}$. のように貫入抵抗と打継ぎ許容時間との関係を求めた。

図一8 はコンクリートに加水してからの経過積算温度 $\left(T^{\circ} T\right.$ : 後述 7) と圧縮ひず夕度, 引張ひずみ度, 圧縮 強度の発現との関係およびコンクリートの凝結の始発, 終結, 硬化開始, 流動状態の変化などを示すものである。

この図では, コンクリートの始発を鳥田博士の提案に 従って ${ }^{1-2)}$ 貫入抵抗 $1 \mathrm{~kg} / \mathrm{cm}^{2}$ としているが，これはセメ ントの終結にほぼ一致している。また終結を $10 \mathrm{~kg} / \mathrm{cm}^{2}$ としてコールドジョイントをさけられる限界としてい る。この時期には, コンクリートは振動機をかけること

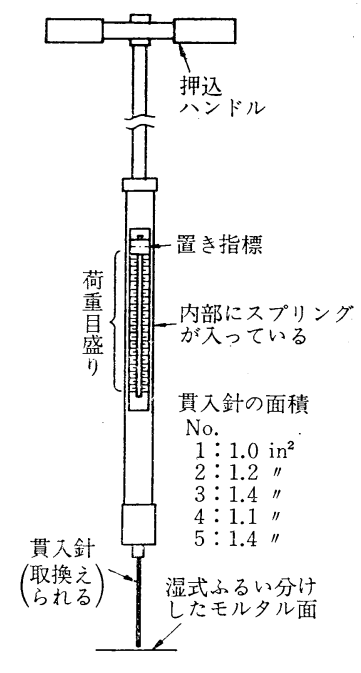

図一7 プロクター貫入試験装置 

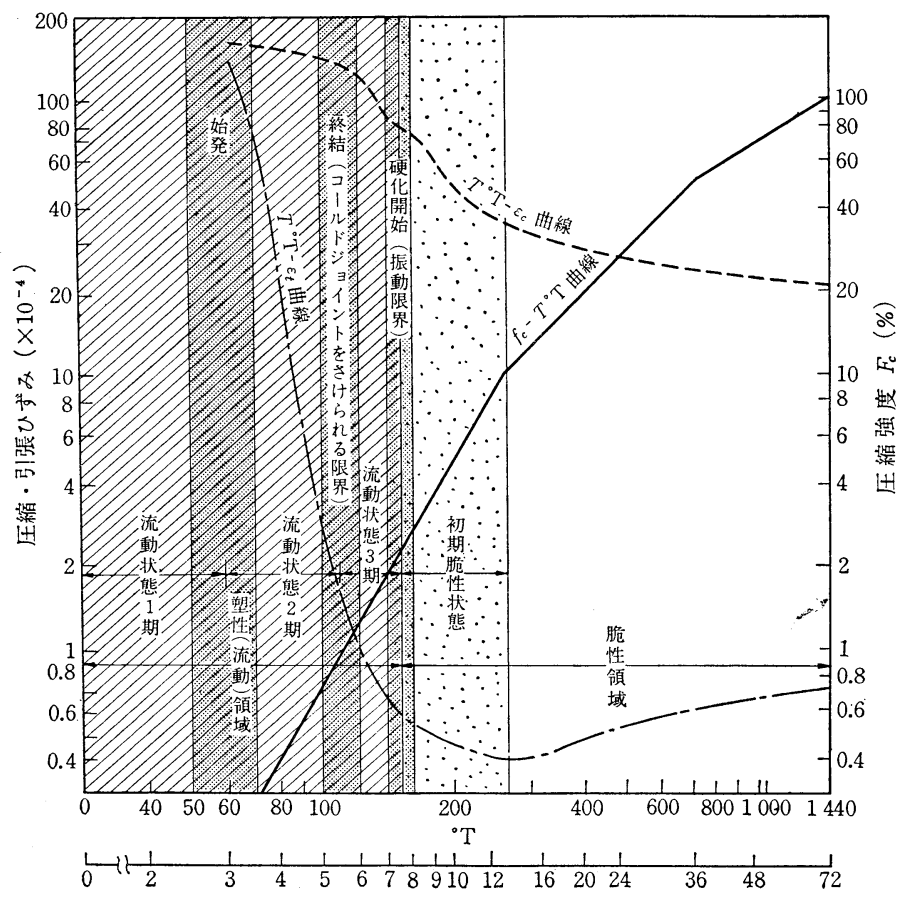

養生温度 $20^{\circ} \mathrm{C}$ における材命時間（h）

図一8 コンクリートの凝結・硬化・初期ひずみなどと $\boldsymbol{T}^{\circ} \boldsymbol{T}$ との関係 $\left(\boldsymbol{T}{ }^{\circ} \boldsymbol{T}-\boldsymbol{\varepsilon}_{c}\right.$ 曲 線は圧縮応力度 $95 \%$ のときの $\boldsymbol{T}^{\circ} \boldsymbol{T}$ と $\boldsymbol{\varepsilon}_{c}$ との関係, $\boldsymbol{T}{ }^{\circ} \boldsymbol{T}-\boldsymbol{\varepsilon}_{t}$ 曲線は引張 応力度 $95 \%$ のときの $T^{\circ} \boldsymbol{T}$ と $\varepsilon_{t}$ との関係, $\boldsymbol{f}_{c}-\boldsymbol{T}^{\circ} \boldsymbol{T}$ 曲線は初期圧縮強度 推定曲線である一いずれもポルトランドセメントの場合) ${ }^{1-10)}$
によってプラスチックにすることができ る。終結が後ってから $20^{\circ} \mathrm{C}$ で 2 時間程 度経過すると，振動機をかけてもコンク リートは最早プラスチックにすることが できない。このときを振動限界とし，硬 化開始としている。この点は先に述べた ASTM の貫入抵抗 $500 \mathrm{psi}$ に相当して いる。

図一9 はコンクリート成型後の経過時 間と円柱供試体の破壊時間との関係を示 すものであるが，はじめは粘土を圧縮し たときのような破壊を示し，やがてたて 方向に多数のひびわれを生ずる破壊を示 し，次に三角錐状の破壊を示すことが観 察される。

\section{5.コンクリートの打継ぎ許} 容時間は温度によってど のよらに変化するか

打継ぎ許容時間とは，コンクリートを 打設してから次の層のコンクリートを打 設するまでに許容されている時間で, 打 放しコンクリートであれば，硬化後打継

普通ポルトランドセメント使用， $W / C=60 \% ， 20^{\circ} \mathrm{C}$ 盖生

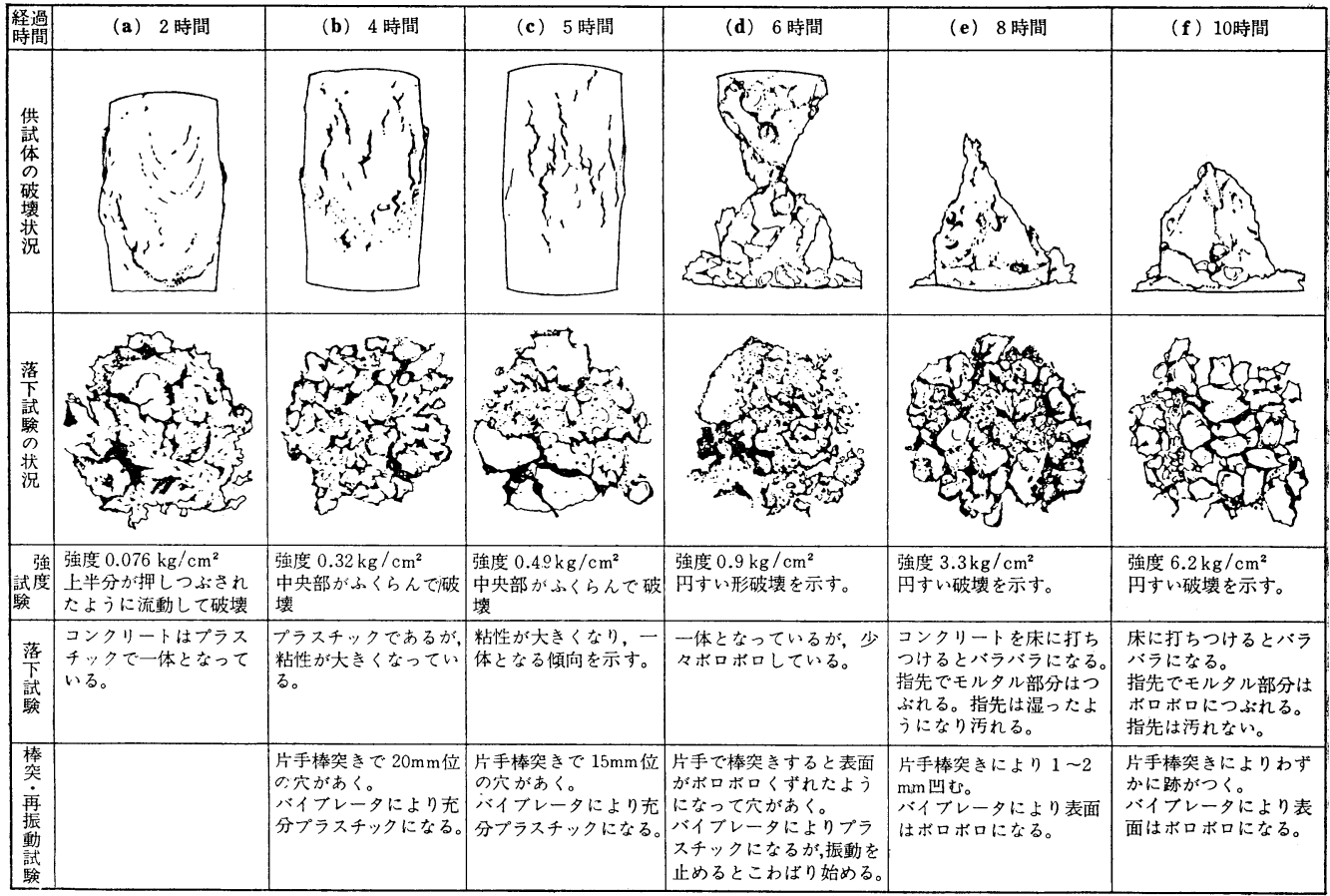

図一9コンクリート供試体の初期破壊状況, 落下試験の状況，その他 ${ }^{1-10}$ 
ぎが見えないようにするための打継ぎ時間の限度は短く なる。

これに対し, タイル張り, 塗料の吹き付け, など仕上 て被覆されるので, 少々打継ぎ部分が目についてもよ い。このようなときは, 打継ぎ許容時間を長くとれる。 このほか夏期はセメントの水和が促進されるので許容時 間は短くなり，冬期は許容時間が長くなる。また打込み までの運搬時間を長く必要としたコンクリートは短時間 で運搬したものより, 許容時間を短くとらなければなら ない。

このように打継ぎ許容時間はコンクリートの打込みに 当って大切なものであるが, 鳥田博士 ${ }^{1-2)}$ はプロクター 貫入抵抗試験を行い，経過時間に伴う貫入抵抗の変化を 測定し，次のような提案を行った。すなわち貫入抵抗が 打放しやそのほか重要な部材の場合 $\cdots \cdots \cdots \cdot \cdots \cdot 1 \mathrm{~kg} / \mathrm{cm}^{2}$ 一般の部材の場合…………………..... $5 \mathrm{~kg} / \mathrm{cm}^{2}$

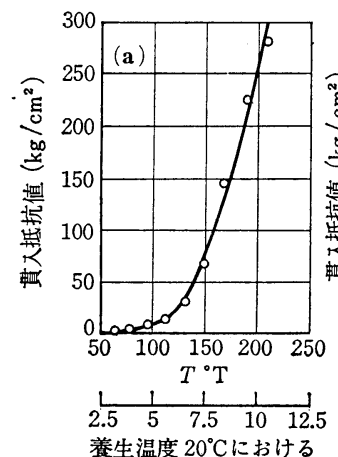
㝨生温度 $20^{\circ} \mathrm{C}$ における

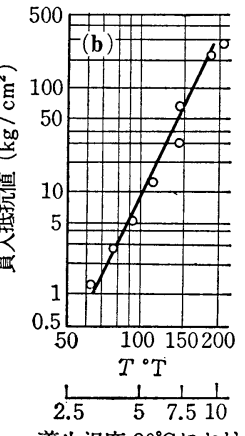

養生温度 $20^{\circ} \mathrm{C}$ における げを施す場合は構造的に一体となっていれば仕上によっ

内部振動，そのほか適当な処理を行う場合 $10 \mathrm{~kg} / \mathrm{cm}^{2}$

筆者はコンクリートの温度, 練りまぜ運搬時間などを 考慮して, 積算温度 $\left(T^{\circ} T\right)$ を用いて, 打継ぎ許容時間 を求めた ${ }^{1-12)}$ 。

一般に貫入抵抗曲線の縦横の軸を普通目盛座標にとっ た図一10（a）のような表現が多いが，これでは貫入抵抗 $1 \sim 10 \mathrm{~kg} / \mathrm{cm}^{2}$ を対象とする打継ぎ許容時間を求めるこ とはできない。図一10(b) のように縦横の座標を対数目 盛にとると, 貫入曲線は直線で表わされ，1１0 kg/ $\mathrm{cm}^{2}$ を正確に示すことができる。横座標として, 積算温度 $\left(T^{\circ} T\right)$ をとることにより，コンクリートの温度を要因 にとり入れたデータを使用することができる。图一11 は貫入抵抗, $1 \mathrm{~kg} / \mathrm{cm}^{2}$ の場合と, $10 \mathrm{~kg} / \mathrm{cm}^{2}$ の場合の打 継ぎ許容時間を求めたものである。コンクリート温度が 高い程, 練りまぜ・運搬時間が長い程許容時間は短くな る。

生コンクリートの配送は定められた許容時間内に次層 のコンクリートが打設できるように行われる必要があ る。

6. 初期ひびわれの防止はどのようにし たらよいか

コンクリートを打込んでから 1 日程度以内に発生した ひびわれを特に初期ひびわれと呼ぶことにすると，コン クリート打込み後 $2 \sim 3$ 時間以内に上端水平鉄筋に沿っ て, コンクリートの沈降によるひびわれが発生すること がある。

この対策は, 単位水量をできるだけ少なくし, 再打法 を行ってひびわれを防止するのがよい。

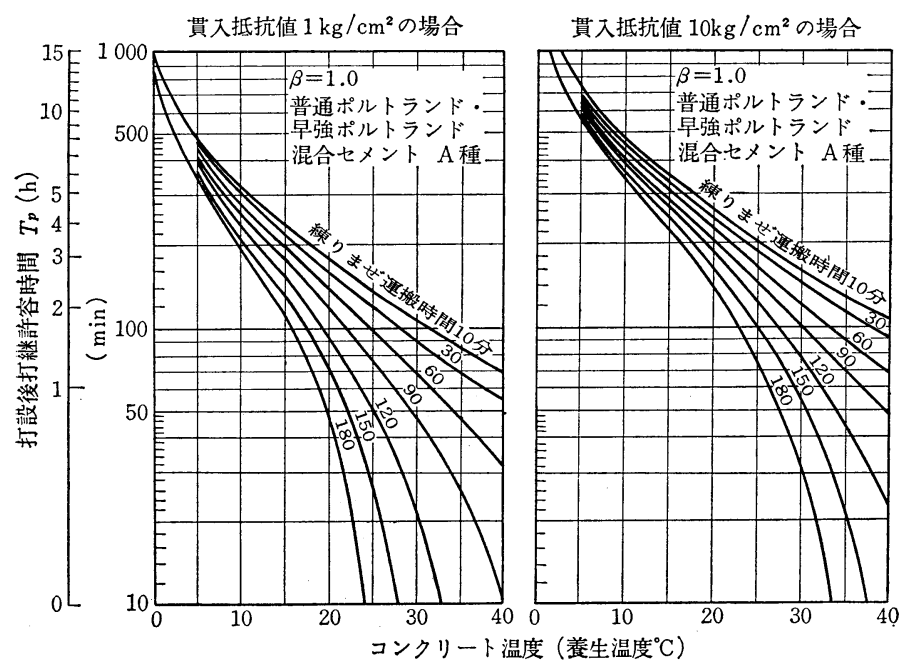

図一11 養生温度と打設後打継ぎ許容時間との関係 関係線でよ(1) ${ }^{1-12)}$ これらについては, 既に 3. で述べた。

ここでは, 細骨材中の洗い試験によっ て失なわれる微粒分及び養生条件を中心 とした初期ひびわれの発生及びその防止 について述べる。

\section{（1）細骨材中の微粒分とひびわれの} 発生

一般に天然細骨材中の微粒分は風化さ れており, 多孔状を呈し, 比表面積が大 きく, 吸水率も大きい。粘土, シルト含 有量も多く, 吸水によって膨潤し, これ が脱水すると，体積の収縮が大きい。

JASS 5 では, 細骨材中の洗い試験に よって失なわれる量の限度を I 級 : $3 \%$ 以下，II級: $4 \%$ 以下，且級: $5 \%$ 以下 と定め, RC示方書では “表面がすりへ 


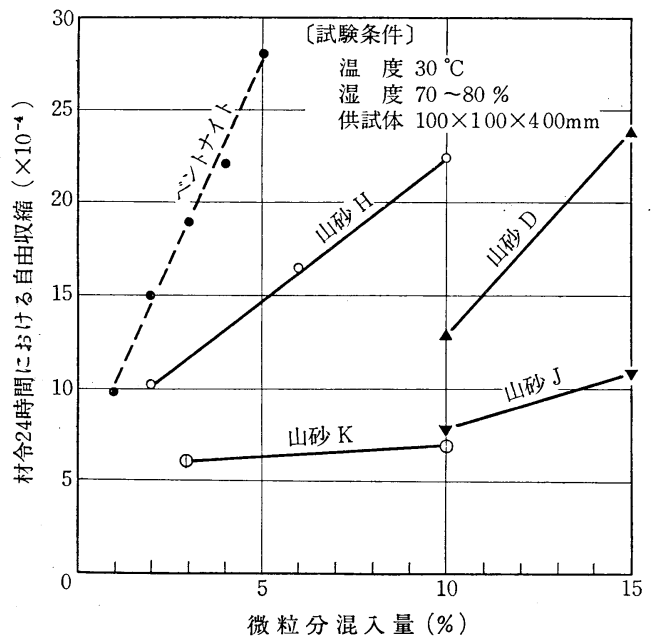

図-12 微粒分の混入量と材令 24 時間までの自由収縮の例 （山砂 $\mathrm{D}, \mathrm{H}$ は粘土分が多く, 常温から $400^{\circ} \mathrm{C}$ ま での重量減少率が大きく，モンモリロナイト，ハロ イサイト等の鉄物含有量が大きいもの。山砂 $\mathbf{J}, \mathbf{K}$ は粘土分が $\mathrm{D}, \mathrm{H}$ より少なく， $400 \sim 600^{\circ} \mathrm{C}$ の重 量減少率が大きく, カオリナイト類の含有量が比較 的大き(いもの) ${ }^{4)}$

り作用を受ける場合最大値 $3.0 \%$, その他の場合最大值 5.0\%”と定められている。

拘束板を用いて，コンクリート打込直後から風にさら し，初期ひびわれの発生実験を行ってみると年，微粒分 の産地・組成によって収縮量及び初期ひびわれの程度が 相違した。图一12 は水セメント比 $65 \%$ ，スランプ 21 $\mathrm{cm}$ のコンクリートを $30^{\circ} \mathrm{C}$ 室中で試験した微粒分混合 量と材令 24 時間の自由収縮との関係である。全般的に みて粘土・シルト分の含有量が多く，かつ常温から 400 ${ }^{\circ} \mathrm{C}$ までの減量の大きいモンモリロナイト，八ロサイト 等の鉱物含有量の多い微粒分は収縮が大きい。

ベントナイトのように膨潤性が甚しいコロイド状微粒 子は収縮が特に大きい。これに対し，上質の砕石粉など は 7 10\% 位混入しても収縮はそれ程大きくならず初期 ひびわれは入りにくい。これらの結果から，コンクリー トの初期収縮は水の乾燥によるセメントペーストの収縮 と同時に吸水膨潤していた粘土・シルト質の微粒分（一 般に吸水率が大きくかつ比表面積が大きい程膨潤性が大 きい）が，水分の乾燥と共に収縮する結果生ずるもの で，両者が重乗して，収縮が大きくなり，ひびわれを発 生するものであることが推論できる。

\section{（2）養生と初期ひびわれの発生}

初期ひびわれは, コンクリート打込後 2〜3 時間経過 して水引けを起し始めた頃から入り始めることが多く, 特に夏期には 2 4 時間に打けるひびわれ発生が多い。 この時期には，引張強度はごく小さく，コンクリートの 破断までの引張ひずみ度が急激に減少して行くときであ

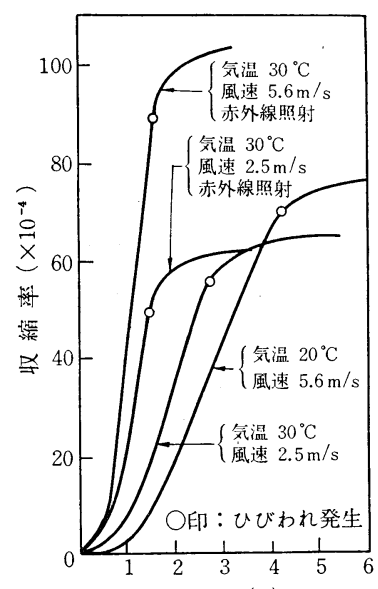

時間 $(h)$

図一13 初期乾燥収縮 (Ravina \& Shalon による) ${ }^{1-36)}$

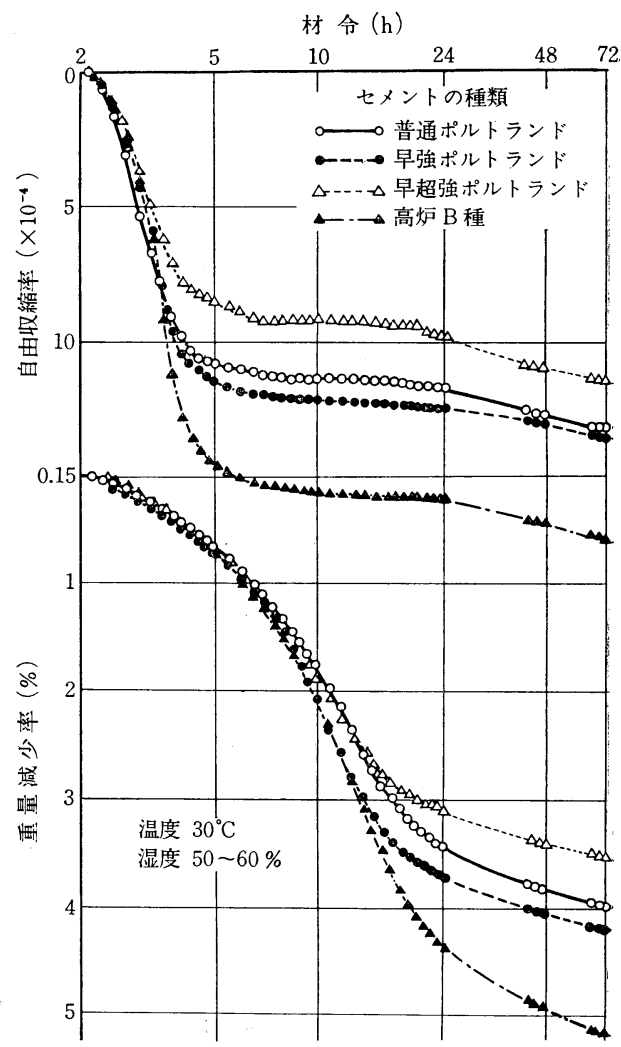

図一14 材令と自由収縮率及び重量減少率との関係 ${ }^{1-5)}$

る (図-8 参照)。夏期，気温が高く風にさらされると， 水の蒸発が速やかで，表面は収縮するが，七メントの水 和によるマトリックスが急速に形成されつつあるので, 蒸発によって失なわれた表面の水を内部から供給する速 度が遅れ，表面の収縮が進み，ひびわれを発生する。図 -13 は風速・温度をかえて収縮を測定し，ひびわれ発 生時間を求めている。温度の高い程, 風速の速い程, 収 縮は大きい。 


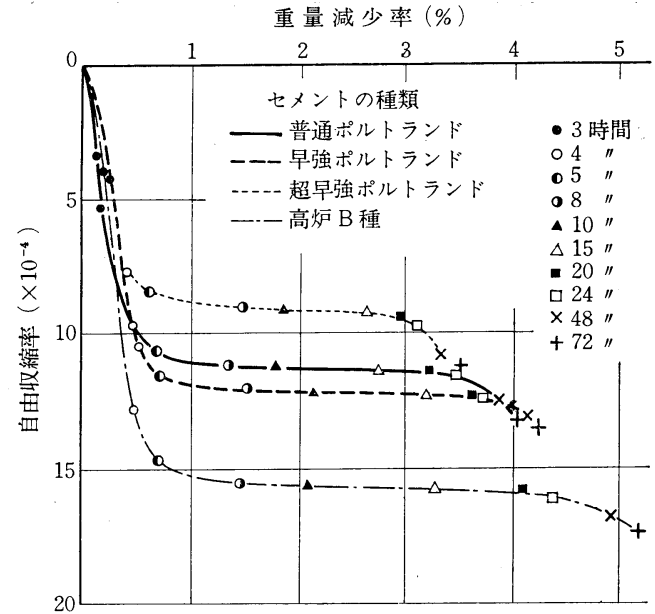

図一15 重量減少率と自由収縮 ${ }^{1-5)}$

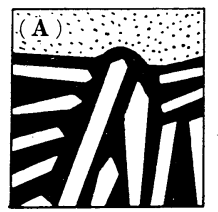

粒子間に多量の 水がある。

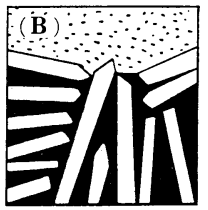

水が減少し, 恒 率乾燥から減率 乾燥に移る。

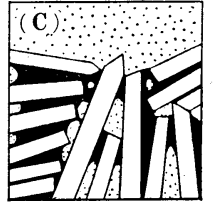

粒子間に空げきが 生ずる。水が減じ ても収縮しない。

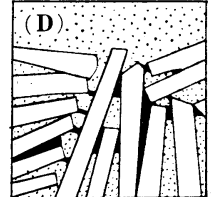

粒子間の水はご く少なくなる。

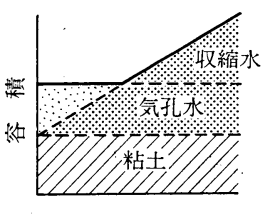

含水率 $(\%)$

(c) 含水率-容積

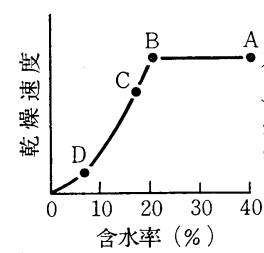

(a) 含水率-乾燥速度

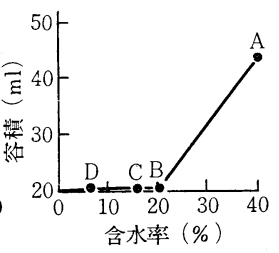

(b) 含水率- 容積
はひびわれが発生したり，生長することが少ない。これ は土の含水量の変化倿する收縮の機構に類似している (図一16 参照)。これをコンクリートに適用すると，9時 間位までの収縮は水の蒸発によってセメント・骨材など の粒子間が接近し，お互いに粒子がせり合って一旦収縮 が止り，その後 3〜4 日までは比較的大きな空隚の水が 蒸発してゆく。そのためかなり水分が乾燥しても水の蒸 発に伴う凝集力（収縮力）が小さいためほとんど収縮し ない。ところが 4，5 日以後はセメントゲルの毛細管内 の水が蒸発するようになり, 乾燥水分の絶対量は少なく とも, 順次毛細管の水が蒸発するため, 水の脱出の際の 毛細管の収縮が大きく，その結果ペーストが収縮するた め，コンクリートが収縮するものと思われる。

このような理由で, 初期 7 8 時間以内の急激な収縮 の際ひびわれを生じなければ，その後は， 3 日，4日までは乾燥によるひびわれは殆 んど発生せず，かつ発生したひびわれの生 長も余りない。長期収縮はその後起こるも のであることが推論できる。

\section{文献}

1）笠井芳夫：コンクリートの初期性状，コンク リートジャーナル Vol. 11, No. 10, Oct. 1973 (初期性状全般に関し，74 の文献を引 用し，総括している。ここで輌義しようとす る初期性状化関する主要な文献は殆んど含ま れているので, 詳細を知り度い方は一読され たい。この講義では, 前記 74 題の文献代含 まれるものの引用は 1-0) の上うにした。例 えば文献 1) 中の文献 5) であれば 1-5）の ように示している)

2）コンクリート工学協会編：コンクリート便覧 第2 編 1.2 凝縮・硬化過程のコンクリート の性質 pp. $28 \sim 43$, 技報堂, 昭 51.6 .

初期収縮は 図一14 に見られるように，30 $30^{\circ}$ で 5 時間 位, $20^{\circ} \mathrm{C}$ で 9 10 時間位まで続く, かつコンクリート の凝結が始まると引張破断時の引張ひずみが急速に小さ くなるので，初期収縮終了までは，コンクリート表面の 急激な乾燥をさけるようにする。

その後は 図一15 亿示すように 3 4 日まで供試体の水 分は乾燥しても收縮は殆んど認められないので，この間
3）神田衛・吉田八郎：コンクリート打込の柱断面における水 セメント比の分布性状, セメント技術年報 XXIX 昭 50 .

4）笠井・横山・松井・三村：細骨材中の微粒分含有量がコン クリートの初期ひびわれにおよぼす影響, 日本建築学会大 会学術講演梗概集 $<$ 構造系>昭 53.9. pp. 493 494

5）笠井・横山・松井・月永：コンクリートの初期収縮に関す 万研究, 日本建築学会関東支部研究報告集 $<$ 材料施工 $>$ 昭 52.7. pp. $309 \sim 312$
鉄筋コンクリート技術の要点

B 5 判 150 頁 定価 1,500 円 送料 200 円（会員 1,200 円）
I . 力学と設計入門

II. 最近の新しいセメントと混和材料

III. コンクリート用骨材と最近の問題点

IV. コンクリートのひびわれ
申込先：（社）日本コンクリートエ学協会
厂 102 千代田区静町 5-7 秀和紀尾井町 TBR 708 TEL : 03-263-1 571 